\title{
WATER OVERFLOW OF THE RIVER ANALYSIS BASED ON THE COMPUTER PROGRAM SIMULATIONS (CPS)
}

\author{
Achmad Syarifudin* \\ Civil and Environmental Engineering Faculty, Universitas Bina Darma, \\ Palembang - 30264, Indonesia \\ Henggar Risa Destania \\ Civil Engineering Faculty, Indo Global Mandiri University, Palembang-30139, Indonesia \\ *Corresponding Author Email: achmad.syarifudin@binadarma.ac.id
}

\begin{abstract}
The purpose of this study is to the analysis of water overflow during wet seasons in Indonesia especially in Palembang district which frequently involved in annual monsoon floods and the question of whether the wells can be used during floods as well as an alternative source when there are no floods. Rainfall intensity is calculated by the first time to calculating the time of concentration and the calculation of the time of concentration using the Kirpich formula. Rainfall intensity has a relationship between the length of rain that lasts and the frequency of rain which is usually called the IDF (Intensity Duration Frequency) curve. From this curve, it can be seen the amount of rainfall intensity with a return period of 2, 5, and 10 years. The result of the research design discharges used for each return period is $\mathrm{Q}_{2}$ of $58.176 \mathrm{~m}^{3} / \mathrm{sec}, \mathrm{Q}_{5}$ of $68.990 \mathrm{~m}^{3} / \mathrm{sec}$, and $\mathrm{Q}_{10}$ of $76.150 \mathrm{~m}^{3} / \mathrm{sec}$. Based on the simulation results using the HEC-RAS 4.1.0 program there was overflowing of the river at stations 800, 900, $1000,1100,1200,1300$ and 1450 with a return period of 2 years and the station of $100,200,300,400,500,600$ and 700 there was no overflow or still safe. In the return period of 5 and 10 years there was overflow at stations 100, 400, 500, 600, 700, 800, $900,1000,1100,1200,1300$, and 1450. While at stations 200 and 300 there was no overflow
\end{abstract}

Keywords: Rainfall Intensity, HEC-RAS 4.1.0 Program, Overflowing.

Cite this Article: Achmad Syarifudin and Henggar Risa Destania, Water Overflow of the River Analysis Based on the Computer Program Simulations (CPS). International Journal of Civil Engineering and Technology, 11(5), 2020, pp. 125-136.

https://iaeme.com/Home/issue/IJCIET?Volume=11\&Issue= 5 


\section{INTRODUCTION}

Palembang is the capital of South Sumatra Province with the northern, eastern, and western boundaries being the Banyuasin District and the southern boundary being the Ogan Ilir Regency. Palembang City is known as a city of trade and also a city of water (water city).

Palembang City has four major rivers that pass through it, namely the Musi River, Komering River, Ogan River, and Keramasan River. In addition to these large rivers that function as urban drainage, one of which is the Aur River. Aur River is located in the Seberang Ulu I District in the 9/10 Ulu area. The 9/10 Ulu area is an area with dense housing and is often flooded [1].

Drainage channels that are no longer able to accommodate the volume of water passing through, sediment deposition, siltation of rivers due to rubbish and household waste and reduced water catchment areas in the watershed cause the 9/10 ulu area were flooded during the rainy season [2].

To reduce the risk of flooding, flood control efforts are needed. Flood control planning can be done well if the flood discharge and flood water level are known. Therefore, hydrological analysis is needed to get the amount of flood discharge and hydraulic analysis to get the flood water level using the HEC-RAS 4.1.0 program [3].

\section{THE MATERIAL AND METHOD}

The method used in this study is the collection of rainfall data to analyze rainfall with certain return periods includes a return period of 2 years, 5 years, and 10 years, after that rainfall intensity is calculated by the first time to calculating the time of concentration. then a rainfall frequency intensity curve is made and calculate the discharge plan for each return period.

The HEC-RAS 4.1.0 program is carried out to predict the overflow of water in rivers at certain places based on the survey results of cross-sections and longitudinal sections of the river [3].

\subsection{Time of Concentration}

Calculation of concentration-time using the kirpich formula[5].

Known parameters:

River Length $(\mathrm{L})=1.45 \mathrm{~km}$

Channel Slope $(S)=0,0004$

$$
\begin{aligned}
& t c=\left\{\left(0.87 \times L^{2}\right) /(1000 \times S)\right\} \\
& \quad=1.7499 \text { hours }
\end{aligned}
$$

The results of the concentration-time will be used in the calculation of the next stage.

\subsection{Rainfall Intensity}

Rainfall intensity has a relationship between the length of rain that lasts and the frequency of rain which is usually given in the form of a curve called the IDF (intensity duration frequency) curve. from this curve it can be seen the amount of rainfall intensity with a return period of 2, 5, and 10 years. The next is the calculation of rainfall intensity for the 2-year return period [4]. 


$$
\begin{aligned}
& \mathrm{I}=\left(\frac{R}{24}\right) \times\left(\frac{24}{t c}\right)^{2 / 3} \\
& =(106.669 / 24) \times(24 / 1.7499)^{2 / 3} \\
& =25.465 \mathrm{~mm} / \text { hour }
\end{aligned}
$$

Table 1 Maximum rainfall in Gumbel distribution

\begin{tabular}{ccc}
\hline $\begin{array}{c}\text { Return Period } \\
\text { (year) }\end{array}$ & $\mathbf{R}_{\mathbf{2 4}}(\mathbf{m m})$ & $\mathbf{I}(\mathbf{m m} /$ hour $)$ \\
\hline 2 & 106.669 & 25.465 \\
5 & 139.519 & 33.308 \\
10 & 161.271 & 38.501 \\
\hline
\end{tabular}

The calculation of intensity for return periods of 2,5 , and 10 years in 10 minutes can be

\begin{tabular}{|c|c|c|c|c|}
\hline \multicolumn{2}{|c|}{ T (time) } & \multicolumn{3}{|c|}{ Return Period } \\
\hline minute & hours & 2 & 5 & 10 \\
\hline 10 & 0.167 & 122.106 & 159.710 & 184.609 \\
\hline 20 & 0.333 & 76.922 & 100.611 & 116.296 \\
\hline 30 & 0.500 & 58.702 & 76.780 & 88.751 \\
\hline 40 & 0.667 & 48.458 & 63.381 & 73.262 \\
\hline 50 & 0.833 & 41.760 & 54.620 & 63.135 \\
\hline 60 & 1.000 & 36.980 & 48.369 & 55.909 \\
\hline 70 & 1.167 & 33.369 & 43.645 & 50.449 \\
\hline 80 & 1.333 & 30.526 & 39.927 & 46.152 \\
\hline 90 & 1.500 & 28.221 & 36.912 & 42.667 \\
\hline 100 & 1.667 & 26.307 & 34.408 & 39.773 \\
\hline 110 & 1.833 & 24.687 & 32.290 & 37.324 \\
\hline 120 & 2.000 & 23.296 & 30.470 & 35.221 \\
\hline 130 & 2.167 & 22.085 & 28.887 & 33.391 \\
\hline 140 & 2.333 & 21.021 & 27.495 & 31.781 \\
\hline 150 & 2.500 & 20.076 & 26.259 & 30.352 \\
\hline 160 & 2.667 & 19.230 & 25.153 & 29.074 \\
\hline 170 & 2.833 & 18.469 & 24.156 & 27.922 \\
\hline 180 & 3.000 & 17.778 & 23.253 & 26.878 \\
\hline 190 & 3.167 & 17.149 & 22.430 & 25.927 \\
\hline 200 & 3.333 & 16.572 & 21.676 & 25.055 \\
\hline 210 & 3.500 & 16.042 & 20.982 & 24.253 \\
\hline 220 & 3.667 & 15.552 & 20.342 & 23.513 \\
\hline 230 & 3.833 & 15.098 & 19.748 & 22.826 \\
\hline 240 & 4.000 & 14.676 & 19.195 & 22.188 \\
\hline 250 & 4.167 & 14.282 & 18.680 & 21.592 \\
\hline 260 & 4.333 & 13.913 & 18.198 & 21.035 \\
\hline 270 & 4.500 & 13.567 & 17.746 & 20.512 \\
\hline 280 & 4.667 & 13.242 & 17.320 & 20.021 \\
\hline 290 & 4.833 & 12.936 & 16.920 & 19.558 \\
\hline 300 & 5.000 & 12.647 & 16.542 & 19.121 \\
\hline 310 & 5.167 & 12.374 & 16.184 & 18.707 \\
\hline 320 & 5.333 & 12.114 & 15.845 & 18.316 \\
\hline 330 & 5.500 & 11.868 & 15.523 & 17.944 \\
\hline 340 & 5.667 & 11.635 & 15.218 & 17.590 \\
\hline 350 & 5.833 & 11.412 & 14.926 & 17.253 \\
\hline 360 & 6.000 & 11.200 & 14.649 & 16.932 \\
\hline
\end{tabular}
seen in Table 2.

Table 2 Rain intensity with a return period and rain distribution 
From the results of the calculation of rainfall intensity for each repetition period in 10 minutes.

The following is an intensity duration frequency (IDF) curve form from the rainfall intensity data that has been obtained which is shown in figure 1 as below [4].

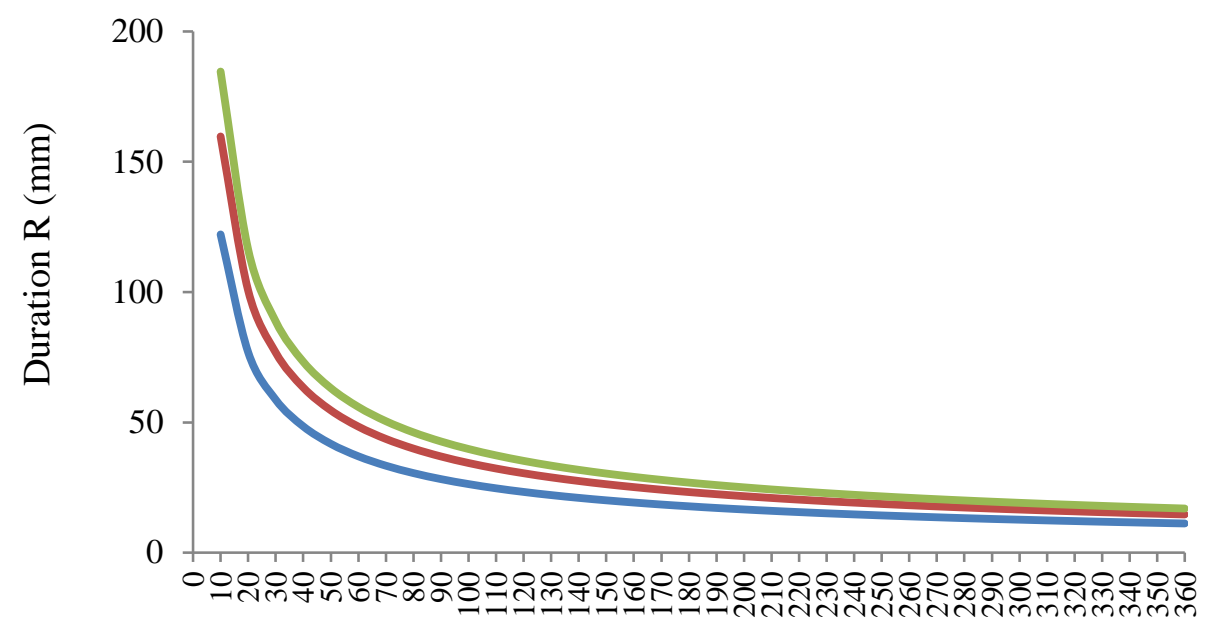

Time (hours)

Figure 1 IDF (Intensity Duration Frequency) Curve

\subsection{Surface Runoff Discharge}

To calculate run-off discharge using the rational method [2].

The following is the calculation of runoff discharge for a 2 year return period.

Known parameters:

Runoff Coefficient $(\mathrm{C})=0.889$

Watershed Area $(\mathrm{A})=5.58 \mathrm{~km} 2$

$$
\begin{aligned}
& \mathrm{Q}=0.278 \text {.C.I.A } \\
& =0.278 \times 0.889 \times 25.464 \times 5.58 \\
& =35,114 \mathrm{~m}^{3} / \mathrm{sec}
\end{aligned}
$$

Table 3 is a recapitulation of Surface Runoff Debit calculations for return periods of 2, 5, and 10 years.

Table 3 Surface Run-off Discharge Calculation

\begin{tabular}{ccccc}
\hline $\begin{array}{c}\text { Return } \\
\text { Period }\end{array}$ & $\mathbf{C}$ & $\mathbf{I}(\mathbf{m m} / \mathbf{h o u r s})$ & $\mathbf{A}\left(\mathbf{k m}^{\mathbf{2}}\right)$ & $\mathbf{Q}\left(\mathbf{m}^{\mathbf{3}} / \mathbf{s e c}\right)$ \\
\hline 2 & 0.89 & 25.465 & 5.58 & 35.114 \\
5 & 0.89 & 33.308 & 5.58 & 45.928 \\
10 & 0.89 & 38.501 & 5.58 & 53.089 \\
\hline
\end{tabular}

\subsection{Hydraulics Analysis}

In the hydraulics analysis, the water level profile is calculated by using some design flood analysis data and drainage channels in the Aur river to get the water level profile. In this analysis the HEC-RAS 4.1.0 program application is also used [3]. 
After getting direct runoff discharge then simulated the results of calculations on existing channels using HEC-RAS 4.1.0. Figure 2 is river segments, namely Aur river, where crosssection data are available.

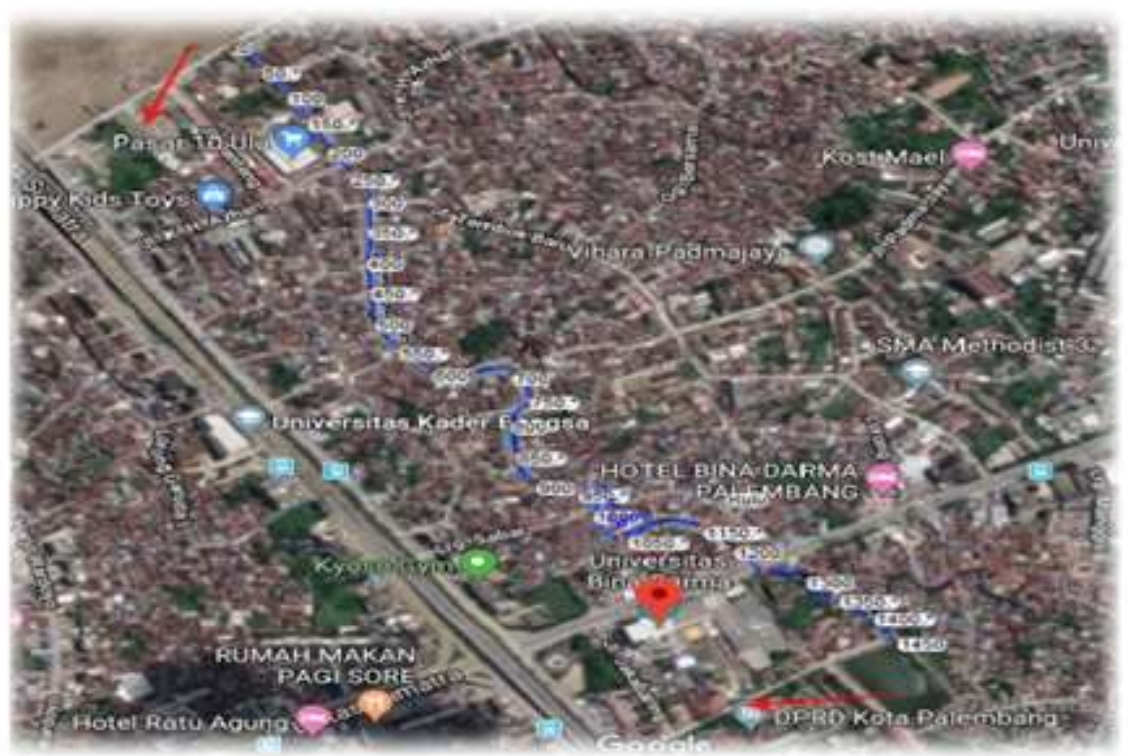

Figure 2 Map used to create a river channel

\subsection{Cross Section}

These data will be inputted in the cross-section can be seen in figure 3 , figure 4 , and figure 5 .

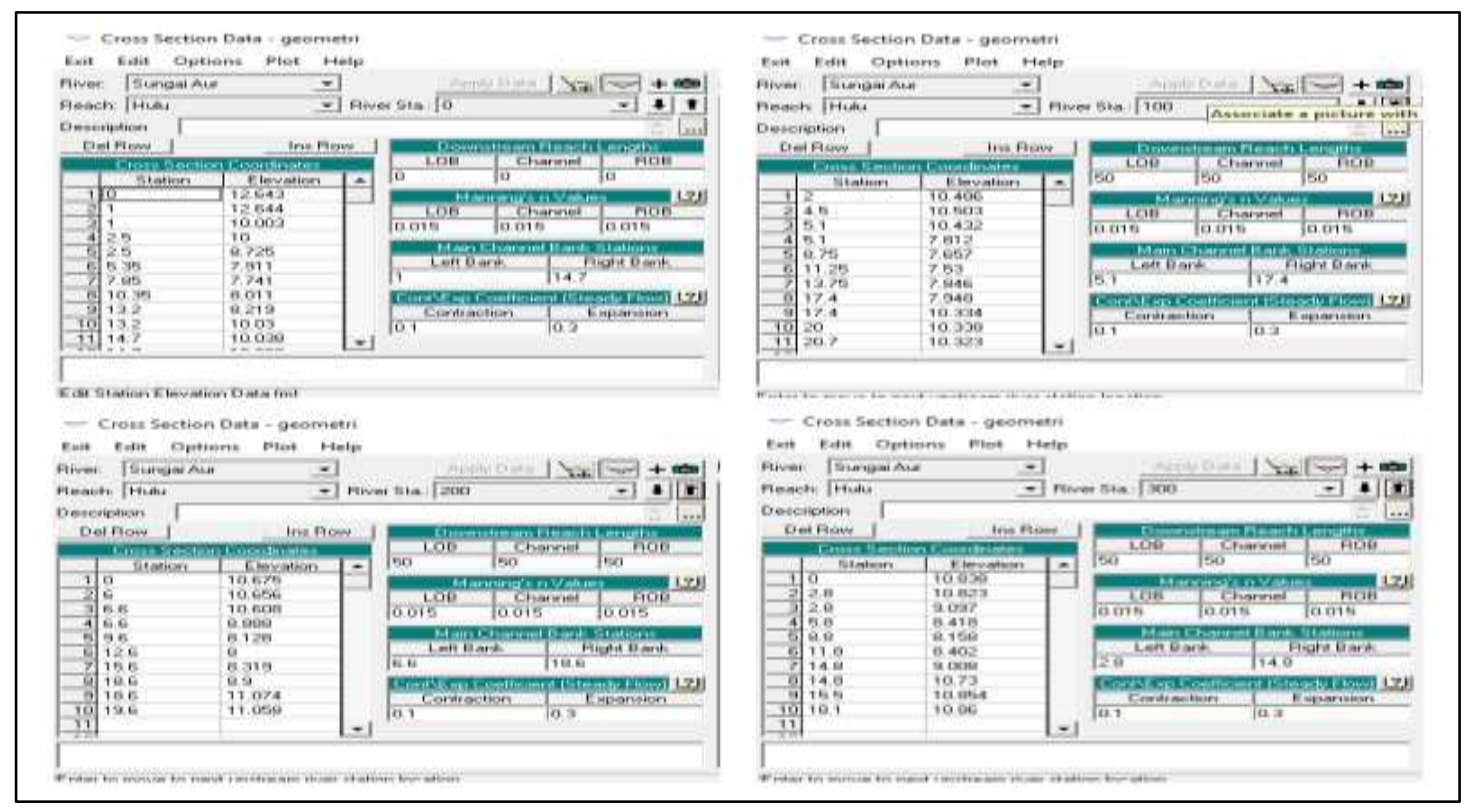

Figure 3 Cross-section data at STA 0 - STA 300 
Water Overflow of the River Analysis Based on the Computer Program Simulations (CPS)

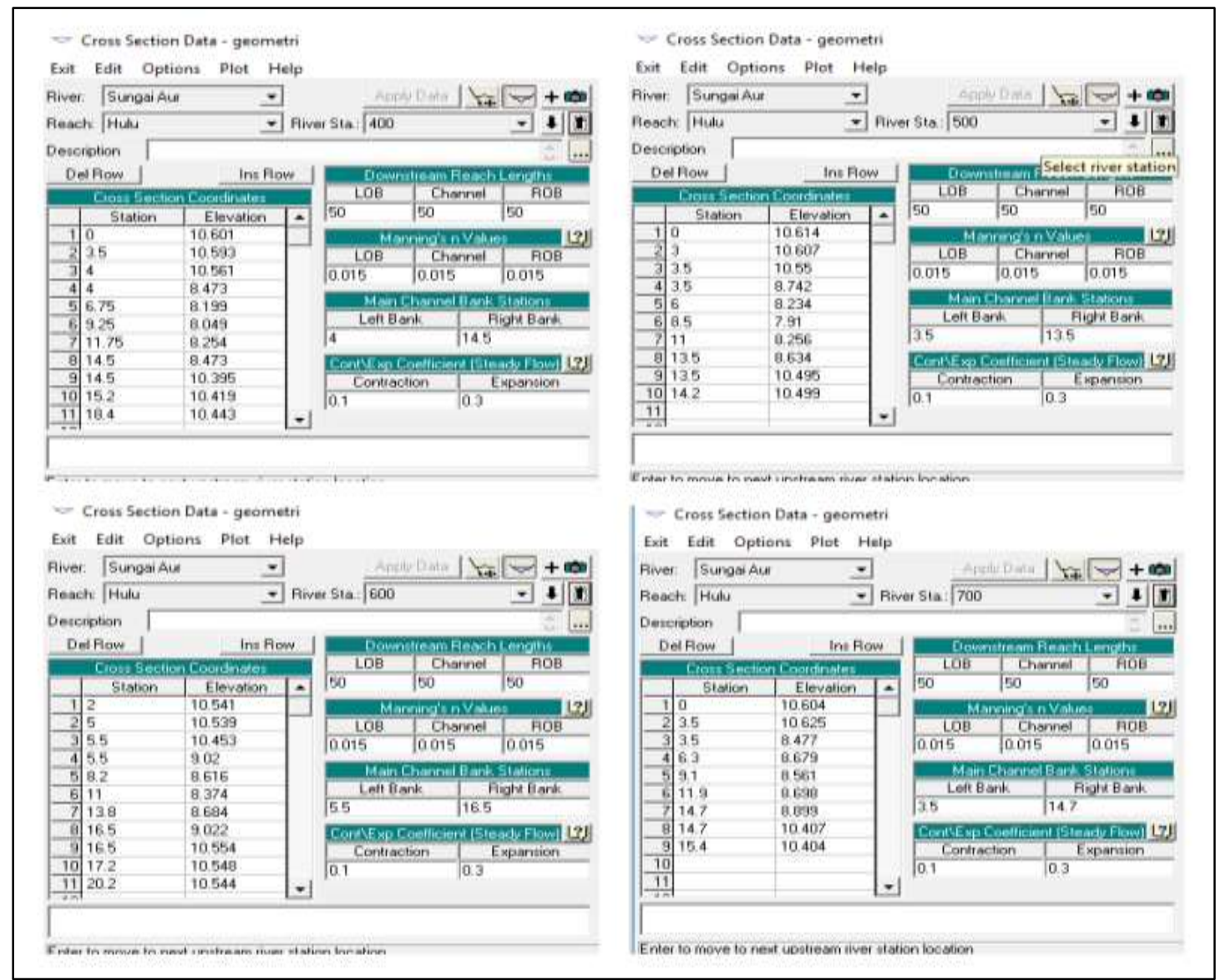

Figure 4 Cross-section data at STA 400 - STA 700

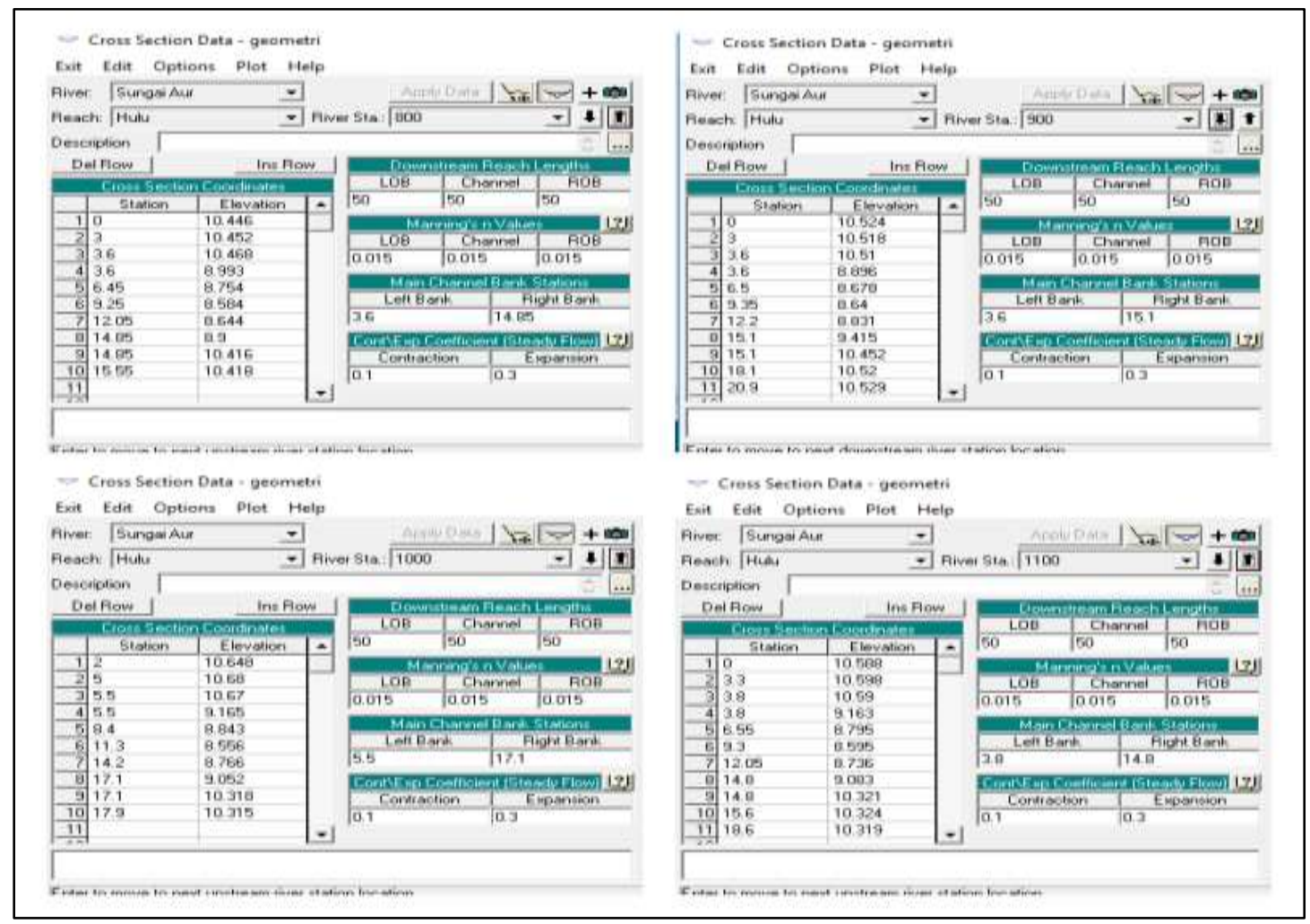

Figure 5 Cross-section data at STA 800 - STA 1,100 


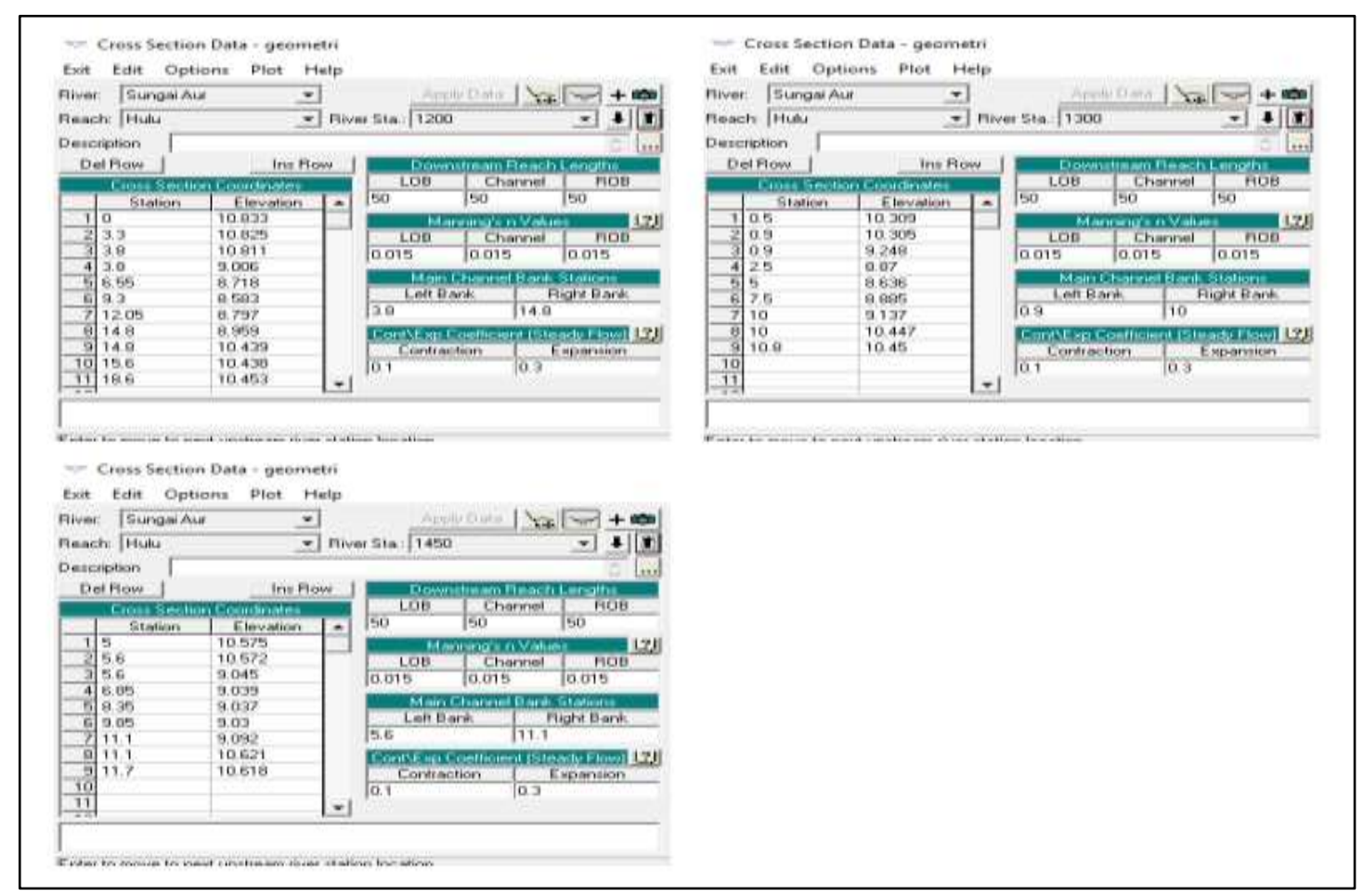

Figure 6 Cross section data on STA 1,200 - STA 1,450

\section{RESULT AND DISCUSSION}

The use of the HEC-RAS 4.1.0 program at the Aur catchment area of Palembang city in analyzing floods and to determine water levels.

From the results of running the HEC-RAS 4.1.0 program on flood discharges with various return periods, namely with $\mathrm{Q}_{2}=58.176 \mathrm{~m}^{3} / \mathrm{sec}, \mathrm{Q}_{5}=68.990 \mathrm{~m}^{3} / \mathrm{sec}$, and $\mathrm{Q}_{10}=76.150 \mathrm{~m}^{3} / \mathrm{sec}$ produce a water level profile at each station.

The results of the analysis, overflowed in the return period of 2 years at stations 800; 900 ; 1,$000 ; 1,100 ; 1,200 ; 1,300$ and 1,450 . In the return period of 5 year and 10 year there was runoff or overflow at stations $100 ; 400 ; 500 ; 600 ; 700 ; 800 ; 900 ; 1,000 ; 1,100 ; 1,200 ; 1,300$ and 1,450. except at stations 200 and 300 .

\subsection{Water Level Fluctuations at STA $0+000$}

With $\mathrm{Q}_{2}=58.176 \mathrm{~m}^{3} / \mathrm{sec}, \mathrm{Q}_{5}=68.990 \mathrm{~m}^{3} / \mathrm{sec}$, and $\mathrm{Q}_{10}=76.150 \mathrm{~m}^{3} / \mathrm{sec}$, the river conditions are still safe or without overflow at sta $0+000$ with and water level $=9.47 \mathrm{~m}$.

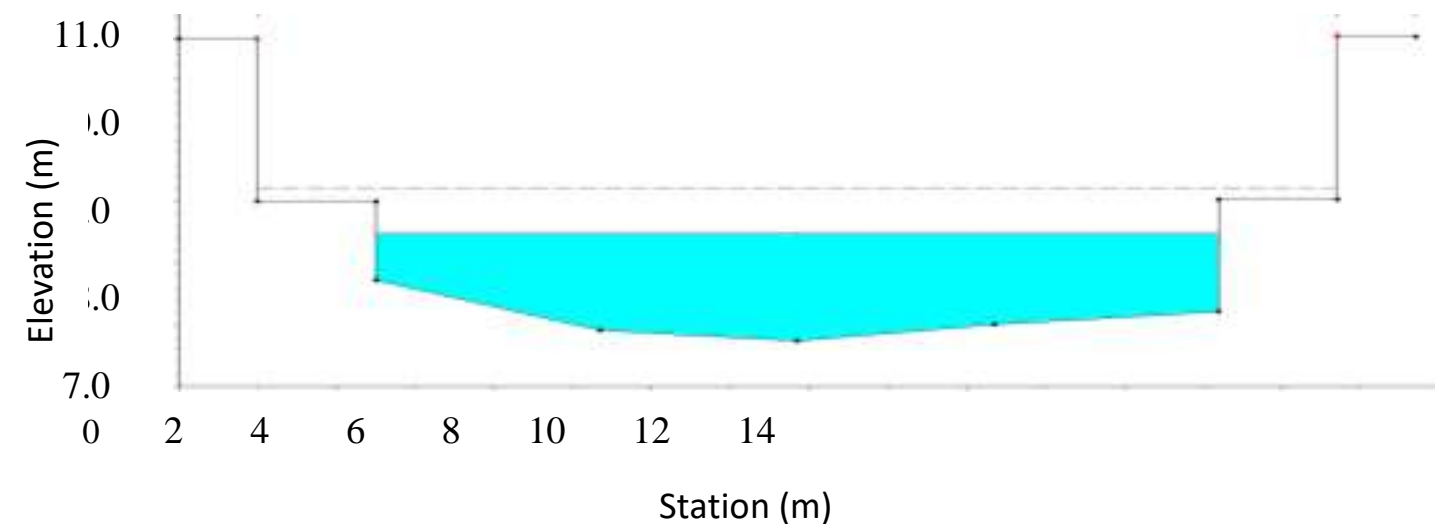

Figure 7 STA $0+000$ water level fluctuations during the 2-year return period 


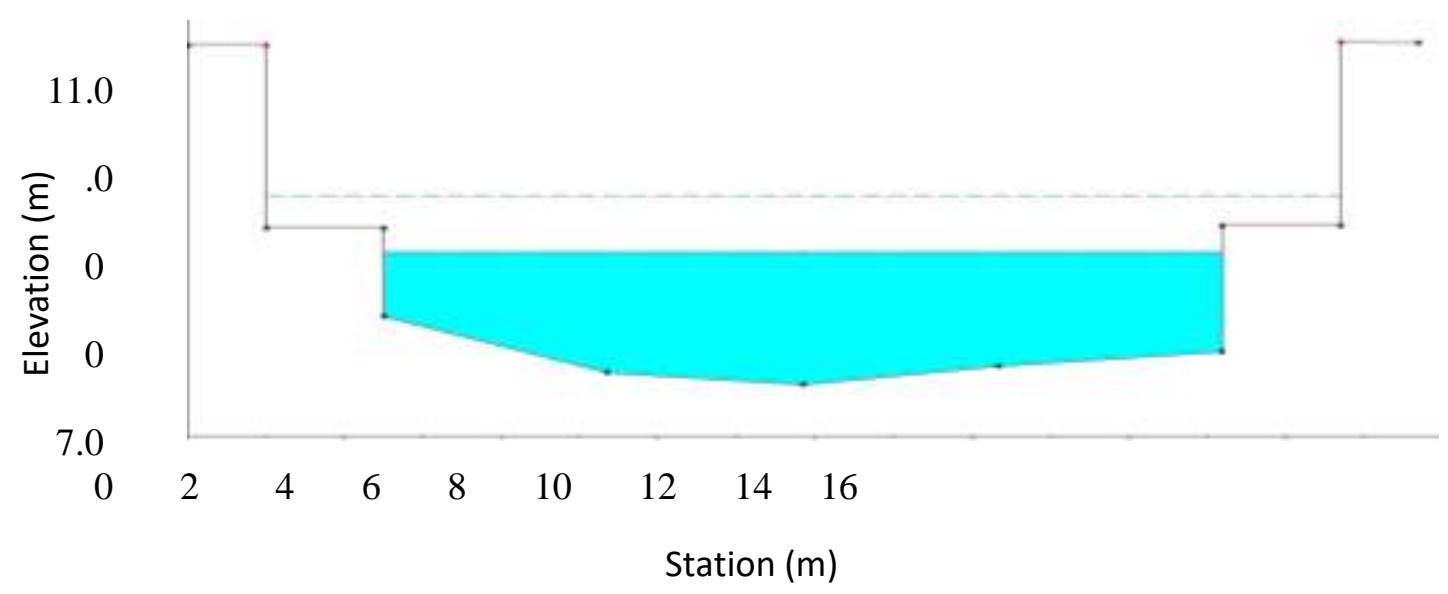

Figure 8 STA $0+000$ water level fluctuations on the 5-year return period

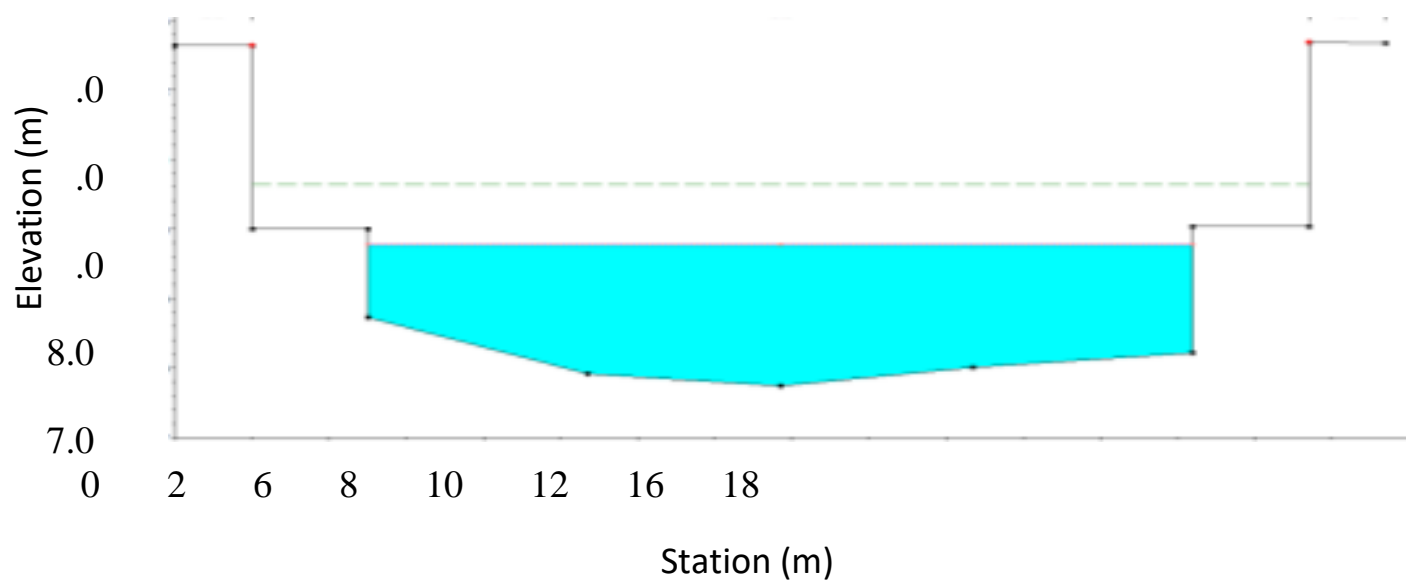

Figure 9 STA $0+000$ water level fluctuations during the 10 -year return period

\subsection{Water Level Fluctuations at STA $0+400$}

With $\mathrm{Q}_{2}=58.176 \mathrm{~m}^{3} / \mathrm{sec}, \mathrm{Q}_{5}=68.990 \mathrm{~m}^{3} / \mathrm{sec}$, and $\mathrm{Q}_{10}=76.150 \mathrm{~m}^{3} / \mathrm{sec}$, where $\mathrm{Q}=58.176$ $\mathrm{m}^{3} / \mathrm{sec}$, the river conditions are still safe without runoff or overflow at sta $0+400$ with water level $=10.36 \mathrm{~m}$ and with return period 2-year and 5-year only.

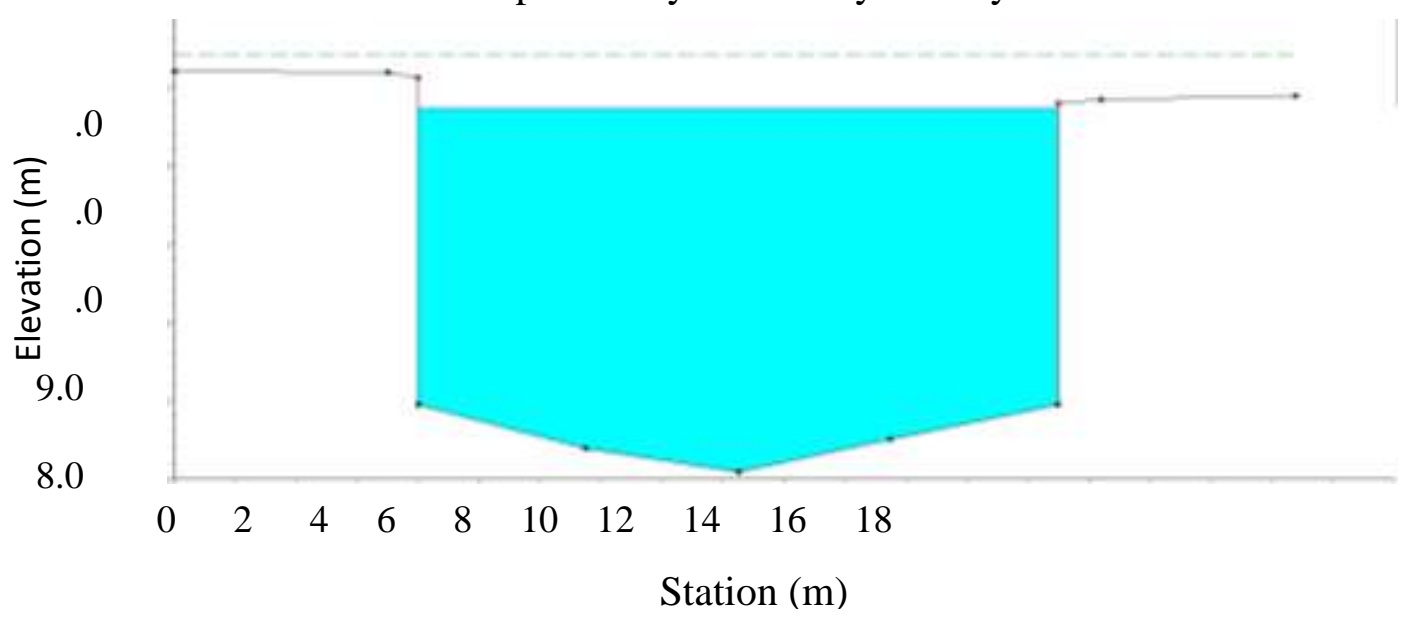

Figure 10 STA $0+400$ water level fluctuation during the 2-year return period 


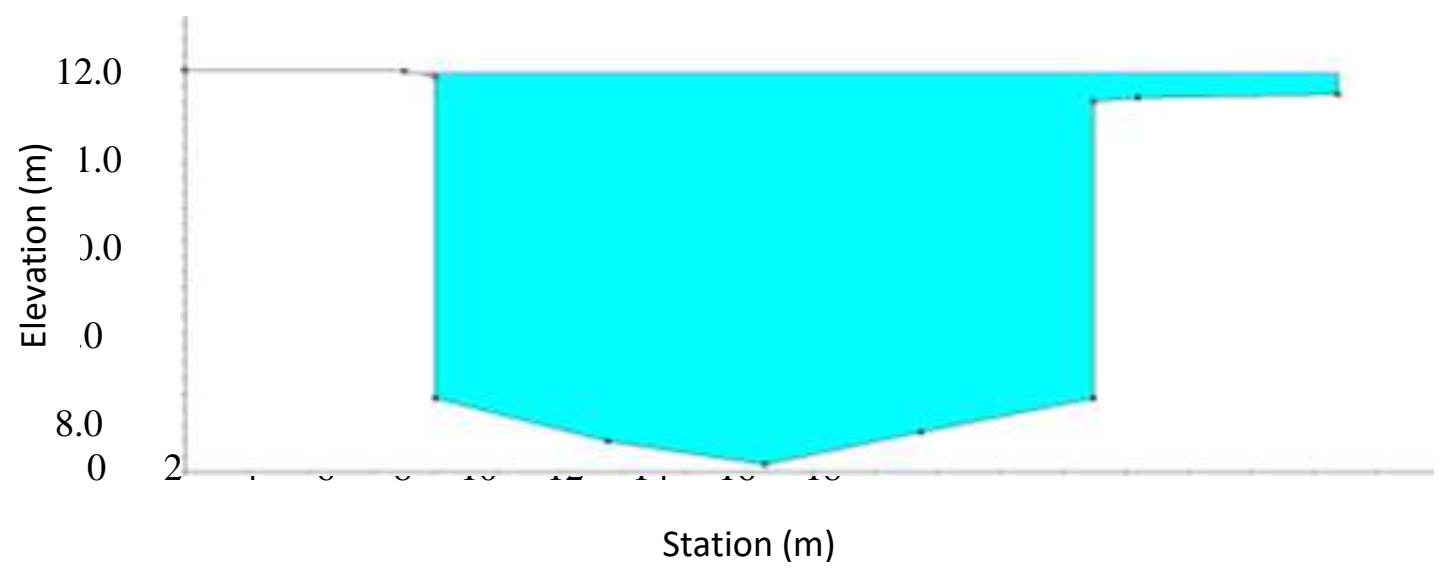

Figure 11 STA $0+400$ water level fluctuation at the 5-year return period

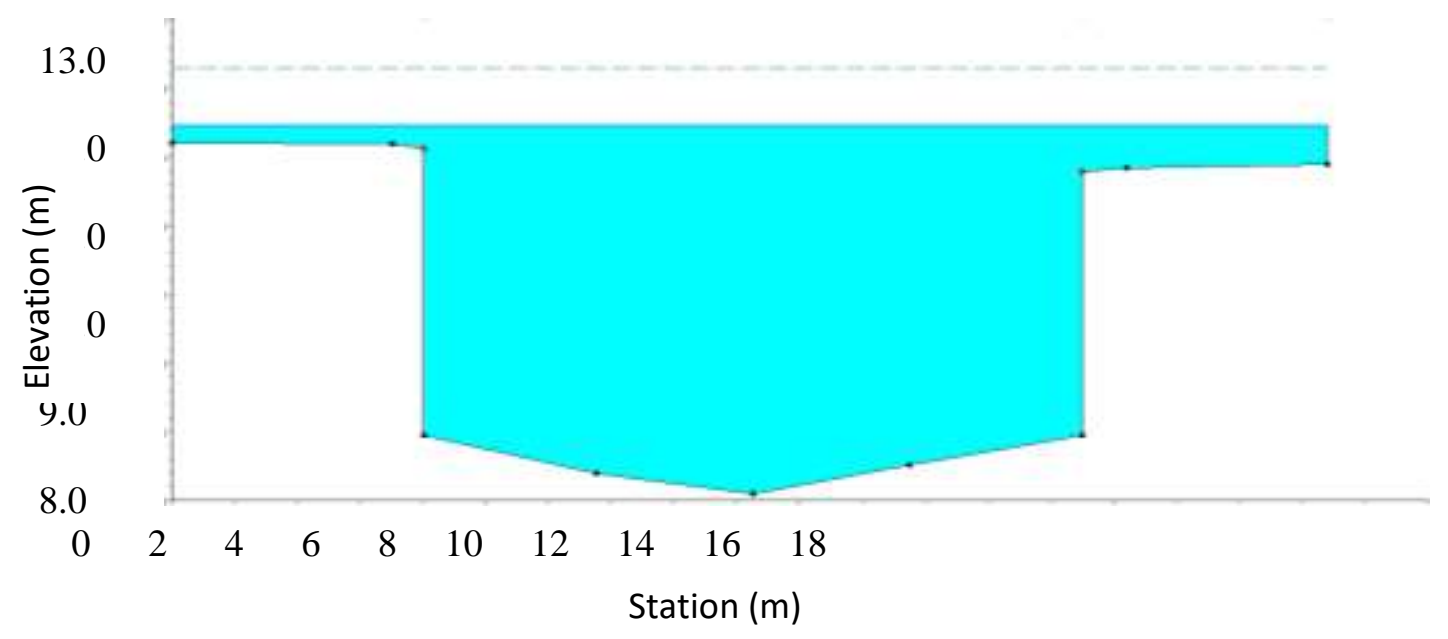

Figure 12 STA $0+400$ water level fluctuation at the 10 -year return period

\subsection{Water Level Fluctuations at STA $1+450$}

With $\mathrm{Q}=58.176 \mathrm{~m}^{3} / \mathrm{sec}, \mathrm{Q}_{5}=68.990 \mathrm{~m}^{3} / \mathrm{sec}$, and $\mathrm{Q}_{10}=76.150 \mathrm{~m}^{3} / \mathrm{sec}$ with a 2-year Return period river conditions have occurred runoff or overflow at STA $1+450$ with water level $=$ $11.30 \mathrm{~m}$ with $0.68 \mathrm{~m}$ overflow.

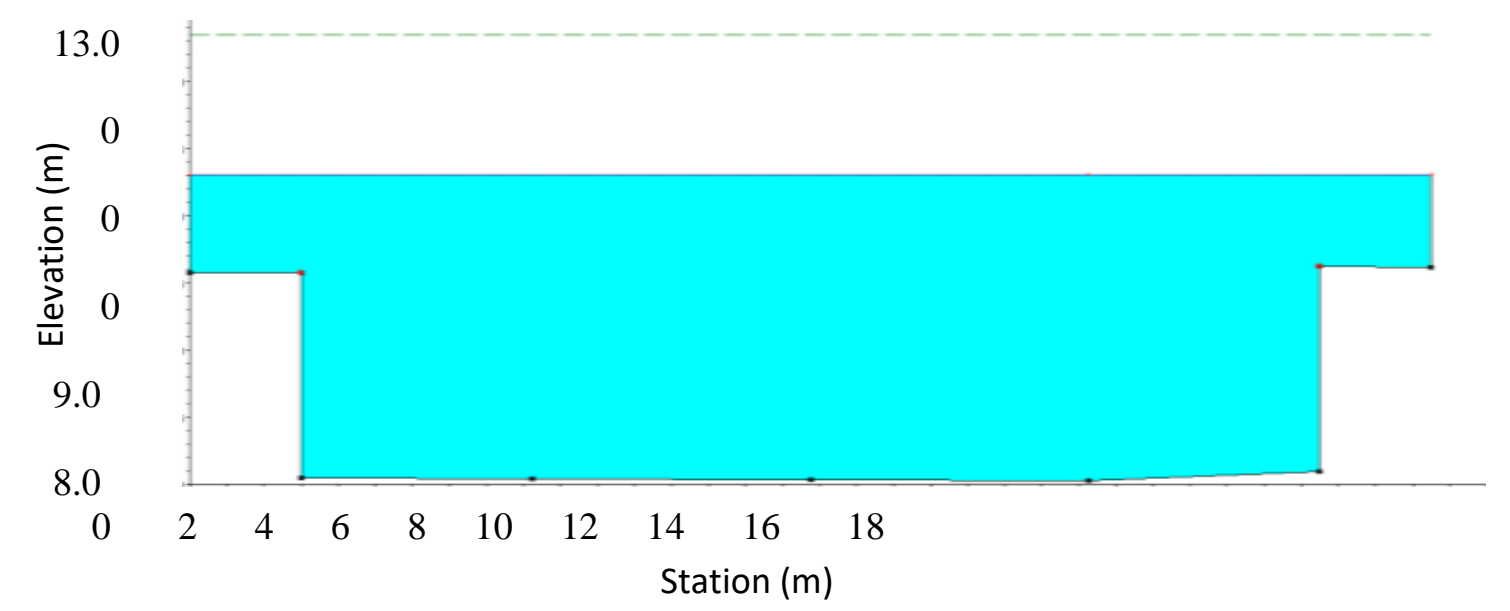

Figure 13 STA $1+450$ water level fluctuation during the 2-year return period 
Water Overflow of the River Analysis Based on the Computer Program Simulations (CPS)

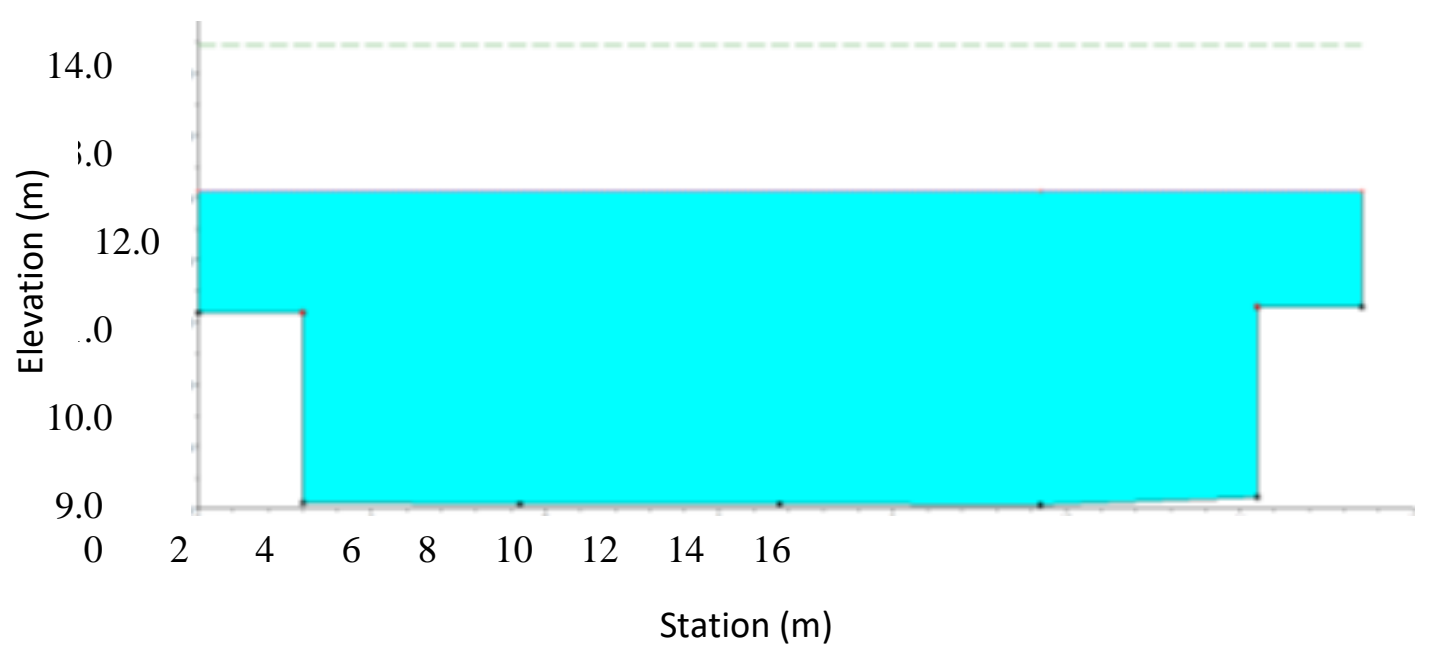

Figure 14 STA $1+450$ water level fluctuation at the 5-year return period

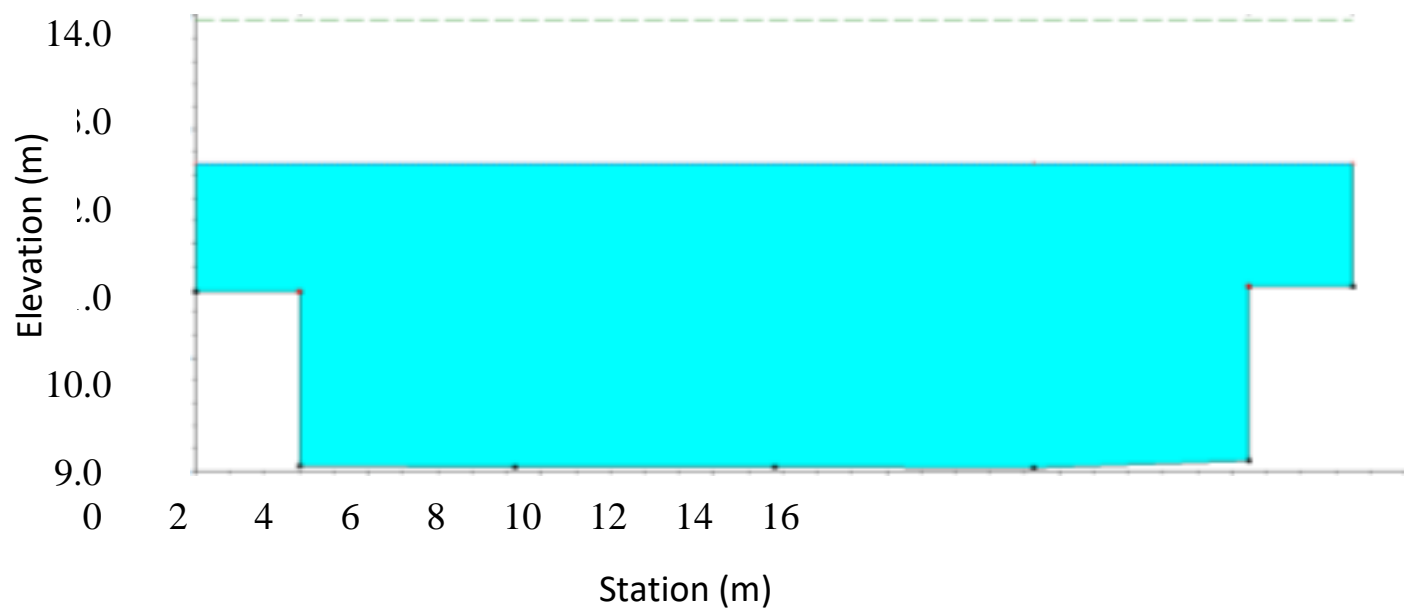

Figure 15 STA $1+450$ water level fluctuation at the 10 -year return period

\section{CONCLUSIONS}

Based on the results and discussion it can be concluded that:

- Design discharges used for each return period are $\mathrm{Q}_{2}$ of $58.176 \mathrm{~m}^{3} / \mathrm{sec}, \mathrm{Q}_{5}$ of 68.990 $\mathrm{m}^{3} / \mathrm{sec}$, and $\mathrm{Q}_{10}$ of $76.150 \mathrm{~m}^{3} / \mathrm{sec}$.

- Based on the simulation results using the HEC-RAS program there was overflowing of the river at stations $800,900,1000,1100,1200,1300$ and 1450 with a return period of 2 years and the station of 100, 200,300,400, 500, 600 and 700 there was no overflow or still safe.

- In the return period of 5 and 10 years there was overflow at stations 100, 400, 500, $600,700,800,900,1000,1100,1200,1300$, and 1450. While at stations 200 and 300 there was no overflow.

\section{ACKNOWLEDGMENTS}

We would like to thank Ir. Djarot Widyoko, MT, Director General of Water Resources, Ministry of Public Works and Housing Indonesia, Dr. Sunda Ariana, M. Pd, MM, Rector of Universitas Bina Darma, and Ir. Suparji, S ST, MT Head of BBWSS-VIII who are pleased to 
give permission and assistance to the author, especially in the preparation of the data so that the paper can be completed.

\section{REFERENCES}

[1] Suripin., Sustainable of Urban Drainage System, 2004, Andi Publishing Company, pp 176-179

[2] Cahyono Ikhsan., Effect of Variation of water discharge on bedload rate on the open channel with steady flow pattern, Civil Engineering Media, 2017, January 2017

[3] Baitullah Al Amin, M., HEC-CRAS Short Tutorial for Beginners. Palembang: Faculty of Civil Engineering, Sriwijaya University, 2016

[4] Syarifudin A., Applied Hydrology, 2017, Andi Publishing Company, pp 45-48

[5] Syarifudin A., Environmentally Urban Drainage, 2017, Andi Publishing Company, pp 3842

[6] Ahmed SMU, Hogue MM and Hossain S, "Floods in Bangladesh: A Hydrological Analysis," Final Report R01/92, Institute of Flood Control and Drainage Research (IFCDR), Bangladesh University of Engineering and Technology(BUET), Dhaka, 1992, pp.1-5

[7] Aureli F and Mignosa P, "Comparison between experimental and numerical results of 2D flows due to levee-breaking," XXIX IAHR Congress Proceedings, Theme C, September 16-21, 2001, Beijing, China

[8] Islam MZ, Okubo K, Muramoto $\mathrm{Y}$, and Morikawa H, "Experimental Study on Sedimentation over the Floodplain due to River Embankment Failure," Bulletin of the Disaster Prevention Research Institute, Kyoto University, 44(2), 1994, pp. 69-92

[9] Ashida K and Michiue M, "Studies on bedload transportation for non-uniform sediment and river bed variation," Disaster Prevention Research Institute Annuals, Kyoto University, No 14B, 1972, pp. 259-273(in Japanese).

[10] Achmad Syarifudin A and Dewi Sartika, A Scouring Patterns Around Pillars of Sekanak River Bridge, Journal of Physics: IOP Conference Series, volume 1167, 2019, IOP Publishing

[11] Syarifudin A, HR Destania., IDF Curve Patterns for Flood Control of Air Lakitan river of Musi Rawas Regency, IOP Conference Series: Earth and Environmental ScienceVolume 448, 2020, The 1st International Conference on Environment, Sustainability Issues and Community Development 23 - 24 October 2019, Central Java Province, Indonesia

[12] Robert. J. Kodoatie, Sugiyanto., Flood causes and methods of control in an environmental perspective, 2002, Yogyakarta

[13] Syarifudin A., The 2nd International Conference on Informatics, Environment, Energy, and Applications (IEEA 2013), Bali, Indonesia, March 16-17, 2013, JOCET (Journal of Clean Energy and Technology) Journal ISSN: 1793-821X Vol. 2, No. 1, January 2014

[14] Shu AP, Tang C, Zhang X, et al., Deposition morphology of non-homogeneous debris flow and its energy characteristics. Journal of Mountain Science, 12(5), 2015, DOI:10.1007/s11629-014-3188-9 
Water Overflow of the River Analysis Based on the Computer Program Simulations (CPS)

[15] Wanshun Zhang, Yanhong Xu, Yanru Wang, and Hong Peng 2014. Modeling Sediment Transport and River Bed Evolution in River System, Journal of Clean Energy Technologies, Vol. 2, No. 2, April 2014

[16] Yang, C.T., Sediment Transport: Theory and Practice. McGraw-Hill, Singapore, 1996.

[17] Department of Public Works., Guidance for Landslide Management Planning, SKBI 2.3.06., 1987, PU Publication Agency Foundation

[18] Van Rijn, L.C., Unified View of Sediment Transport by Currents and Waves II: Suspended Transport. Journal of Hydraulic Engineering, Vol. 133, Issue 6, 2007, pp. 668689.

[19] Syarifudin A., 5th ICIBA International conference on information technology \& Engineering Application, 2015, Palembang

[20] Achmad Syarifudin., The influence of Musi River Sedimentation to The Aquatic Environment DOI: 10.1051/matecconf/201710104026, MATEC Web Conf, 101, 04026, 2017, [published online 09 March 2017] 